\title{
STRENGTH OF THE THREE LAYER BEAM WITH TWO BINDING LAYERS
}

\author{
M. J. SMYCZYŃSKI ${ }^{1}$, E. MAGNUCKA-BLANDZI ${ }^{2}$
}

\begin{abstract}
The paper is devoted to the strength analysis of a simply supported three layer beam. The sandwich beam consists of: two metal facings, the metal foam core and two binding layers between the faces and the core. In consequence, the beam is a five layer beam. The main goal of the study is to elaborate a mathematical model of this beam, analytical description and a solution of the three-point bending problem. The beam is subjected to a transverse load. The nonlinear hypothesis of the deformation of the cross section of the beam is formulated. Based on the principle of the stationary potential energy the system of four equations of equilibrium is derived. Then deflections and stresses are determined. The influence of the binding layers is considered. The results of the solutions of the bending problem analysis are shown in the tables and figures. The analytical model is verified numerically using the finite element analysis, as well as experimentally.
\end{abstract}

Keywords: metal foams; sandwich beams; deflections; stresses, analytical description and solution; nonlinear hypothesis

\section{INTRODUCTION}

Sandwich structures have been widely applied since the mid of the $20^{\text {th }}$ century, for example in aerospace, automotive, rail and shipbuilding industry. These structures are characterized by high stiffness in relation to their mass. Ashby et al. [1] described the mechanical properties of metal foams. Banhart [2] provided a comprehensive description of various manufacturing processes of metal foams and porous metallic structures. Jasion et al. [6], Jasion and Magnucki [7], [8] studied analytically,

\footnotetext{
${ }^{1}$ PhD., Eng., Poznan University of Technology, Institute of Applied Mechanics, Poznan, Poland, e-mail: mikolaj.smyczynski@put.poznan.pl,

${ }^{2}$ DSc., PhD., Eng., Poznan University of Technology, Institute of Mathematics, Poznan, Poland, e-mail: ewa.magnucka-blandzi@put.poznan.pl
} 
numerically and experimentally the global and local buckling-wrinkling of the face sheets of sandwich beams. Gosowski and Kozow [4] presented a distributional solution of the continuous sandwich panel (beam) bending problem. They carried out a numerical analyses based on this solution in order to illustrate the effect of the spacing of intermediate supports and their compliance on the strain of continuous sandwich panels, and the joints fixing them to the steel framing. Ostwald [16] presented multiobjective optimization of the thin-walled sandwich cylindrical shells subjected to axial compression with core of different mechanical properties. Muc and Zuchara [15] established an approach for analyzing the effect of shear deformations in sandwich plates and panels having fibre reinforced plastic faces using a formulation based on the Hamilton principle. Małachowski et al. [13] presented the experimental investigations and numerical modeling of closed-cell aluminum alloy foam (Alporas). Magnucka-Blandzi and Magnucki [10] optimized the sandwich beam with a metal foam core under strength and stability constrains. Magnucki et al. [11], [12] presented the strength analysis of a simply supported five layer sandwich beams with a metal foam core. Smyczynski and Magnucka-Blandzi [21] analysed the stability of a five layer sandwich beam with the use of broken line hypothesis of the deformation of a flat cross section of the beam. Grygorowicz et al. [5] studied analytically and numerically the elastic buckling of a three-layered beam with variable mechanical properties of the core. Loja et al. [9] considered the use of different shear deformation theories to formulae different layerwise models, implemented through kriging-based finite elements. They solved the dynamic problem in the frequency domain of soft core sandwich beams. Mohanty et al. [14] presented the evaluation of the static and the dynamic behavior of functionally graded Timoshenko beams. Smith et al. [20] and Szyniszewski et al. [22], [23] characterized mechanical properties of hollow sphere steel foam. They provided and verified a new design method for the inplane compressive strength of steel sandwich panels comprised of steel face sheets and foamed steel cores. Romanow and Malinowski [17] presented a linear approach to the deflection of sandwich shells and hyperbolic state of displacement of the core as regards dynamic stability. Cernescu and Romanoff [3] proposed a correction to the first and Reddy's third order shear deformation theory to determine the bending deflection of sandwich beams. Shimizu [19] studied numerically the strength and behaviour of sandwich plates as the the laminated damping steel plates which is composed of a soft core subtended by two steel surface layers. Salami et al. [18] presented an advanced high order sandwich panel theory for bending analysis of the moderately thick faced sandwich beams with a soft core. Wang et al. [24] performed a three-point bending of a new composite structure based on aluminum foam sandwich and fiber metal laminate. 
The present paper is devoted to the strength analysis of a simply supported sandwich beam, which consists of five layers: two thin facings (aluminium sheets) of a thickness $h_{f}$, one core (an aluminium foam) of a thickness $h_{c}$ and two thin binding layers (e.g. glue) of a thickness $h_{b}$. The mechanical properties are different for each layer, and depend on its material. The beam has the length $L$, the width $b$ and the total depth $H$. The beam carries a transverse load $F$ (Fig.1).

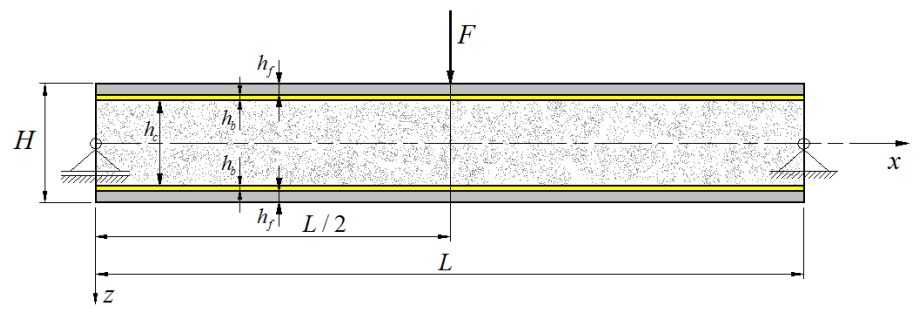

Fig 1. Scheme of the five layer beam subjected to a transverse force

\section{NONLINEAR HYPOTHESIS OF DEFORMATION OF A FLAT CROSS SECTION OF THE BEAM}

The field of displacement for the flat cross section of the five layer beam is presented in Figure 2 . Assuming the nonlinear hypothesis the shear effect is taken into account.
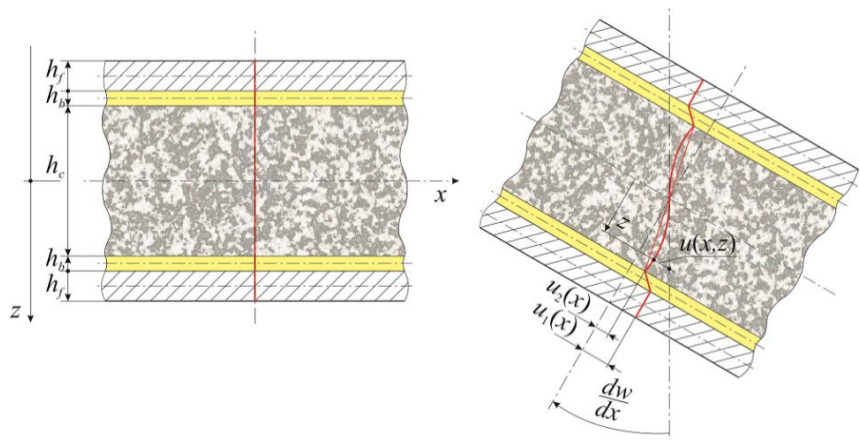

Fig 2. The field of displacement - a nonlinear hypothesis

The longitudinal displacements on the basis of the above hypothesis are formulated as follows:

1. for the upper facing $\quad-\left(1 / 2+x_{1}+x_{2}\right) \leq \zeta \leq-\left(1 / 2+x_{1}\right)$

$$
u(x, \zeta)=-h_{c}\left[\zeta \frac{d w}{d x}+\psi_{1}(x)\right]
$$


2. for the upper binding layer $\quad-\left(1 / 2+x_{1}\right) \leq \zeta \leq-1 / 2$

$$
u(x, \zeta)=-h_{c}\left\{\zeta \frac{d w}{d x}+\psi_{2}(x)-\frac{1}{x_{1}}\left(\zeta+\frac{1}{2}\right)\left[\psi_{1}(x)-\psi_{2}(x)\right]\right\}
$$

3. for the core

$$
-1 / 2 \leq \zeta \leq 1 / 2
$$

$$
u(x, \zeta)=-h_{c}\left\{\zeta\left[\frac{d w}{d x}-2 \psi_{2}(x)\right]+\frac{1}{2 \pi} \psi_{3}(x) \sin (2 \pi \zeta)\right\}
$$

4. for the lower binding layer $\quad 1 / 2 \leq \zeta \leq 1 / 2+x_{1}$

$$
u(x, \zeta)=-h_{c}\left\{\zeta \frac{d w}{d x}-\psi_{2}(x)-\frac{1}{x_{1}}\left(\zeta-\frac{1}{2}\right)\left[\psi_{1}(x)-\psi_{2}(x)\right]\right\}
$$

5. for the lower facing

$$
1 / 2+x_{1} \leq \zeta \leq 1 / 2+x_{1}+x_{2}
$$

$$
u(x, \zeta)=-h_{c}\left[\zeta \frac{d w}{d x}-\psi_{1}(x)\right]
$$

where

$x_{1}=h_{b} / h_{c}, x_{2}=h_{f} / h_{c}-$ dimensionless parameters,

$\zeta=z / h_{c}-$ dimensionless coordinate,

$w$ - deflection,

$\psi_{1}(x)=u_{1}(x) / h_{c}, \psi_{2}(x)=u_{2}(x) / h_{c}, \psi_{3}(x)$ - dimensionless functions of displacement, which determine the field of displacements, and displacements $u_{1}, u_{2}$ are indicated in Fig. 2 ..

If $\psi_{3} \equiv 0$ then the proposed nonlinear hypothesis becomes the broken line hypothesis. So the assumed hypothesis is a generalization of the classical one described in [12, 21].

Strains of the layers of the five layer beam are defined by the following geometric relations:

$$
\varepsilon_{x}=\frac{d u}{d x}, \gamma_{x z}=\frac{d w}{d x}+\frac{d u}{d z}
$$

so

1. for the upper facing $\quad-\left(1 / 2+x_{1}+x_{2}\right) \leq \zeta \leq-\left(1 / 2+x_{1}\right)$

$$
\varepsilon_{x}=-h_{c}\left(\zeta \frac{d^{2} w}{d x^{2}}+\frac{d \psi_{1}}{d x}\right), \quad \gamma_{x z}=0
$$

2. for the upper binding layer $\quad-\left(1 / 2+x_{1}\right) \leq \zeta \leq-1 / 2$ 


$$
\begin{gathered}
\varepsilon_{x}=-h_{c}\left[\zeta \frac{d^{2} w}{d x^{2}}+\frac{d \psi_{2}}{d x}-\frac{1}{x_{1}}\left(\zeta+\frac{1}{2}\right)\left(\frac{d \psi_{1}}{d x}-\frac{d \psi_{2}}{d x}\right)\right] \\
\gamma_{x z}=\frac{1}{x_{1}}\left(\psi_{1}-\psi_{2}\right),
\end{gathered}
$$

3. for the core

$$
-1 / 2 \leq \zeta \leq 1 / 2
$$

$$
\begin{gathered}
\varepsilon_{x}=-h_{c}\left[\zeta\left(\frac{d^{2} w}{d x^{2}}-2 \frac{d \psi_{2}}{d x}\right)+\frac{1}{2 \pi} \frac{d \psi_{3}}{d x} \sin (2 \pi \zeta)\right], \\
\gamma_{x z}=2 \psi_{2}(x)-\psi_{3}(x) \cos (2 \pi \zeta),
\end{gathered}
$$

4. for the lower binding layer $\quad 1 / 2 \leq \zeta \leq 1 / 2+x_{1}$

$$
\begin{gathered}
\varepsilon_{x}=-h_{c}\left[\zeta \frac{d^{2} w}{d x^{2}}-\frac{d \psi_{2}}{d x}-\frac{1}{x_{1}}\left(\zeta-\frac{1}{2}\right)\left(\frac{d \psi_{1}}{d x}-\frac{d \psi_{2}}{d x}\right)\right], \\
\gamma_{x z}=\frac{1}{x_{1}}\left(\psi_{1}-\psi_{2}\right),
\end{gathered}
$$

5. for the lower facing

$$
\begin{gathered}
1 / 2+x_{1} \leq \zeta \leq 1 / 2+x_{1}+x_{2} \\
\varepsilon_{x}=-h_{c}\left(\zeta \frac{d^{2} w}{d x^{2}}-\frac{d \psi_{1}}{d x}\right), \quad \gamma_{x z}=0 .
\end{gathered}
$$

Stresses in all layers of the beam, according to Hooke's law, for individual layers are

$$
\sigma_{x}=E \varepsilon_{x}, \quad \tau_{x z}=G \gamma_{x z}
$$

\section{EQUATIONS OF EQUILIBRIUM}

Based on the principle of stationary total potential energy

$$
\delta\left(U_{\varepsilon}-W\right)=0
$$

the system of four equations of equilibrium was obtained.

The elastic strain energy of the beam

$$
U_{\varepsilon}=\frac{1}{2} \iiint_{V}\left(\varepsilon_{x} \sigma_{x}+\gamma_{x z} \tau_{x z}\right) d V
$$

where $G_{c}=E_{c} / 2\left(1+v_{c}\right)$ - shear modulus of the core, $G_{b}=E_{b} / 2\left(1+v_{b}\right)-$ shear modulus of the binding layers, $E_{c}, E_{b}-$ Young's moduli of the core and binding layers respectively.

The work $W$ of the load is as follows: 


$$
W=\int_{0}^{L} q w(x) d x
$$

where $q$ - continuous load intensity of a constant value.

The system of four equations of equilibrium has been derived based on the principle (3.1):

$$
\left\{\begin{array}{l}
a_{11} \frac{d^{4} w}{d x^{4}}-a_{12} \frac{d^{3} \psi_{1}}{d x^{3}}-a_{13} \frac{d^{3} \psi_{2}}{d x^{3}}+a_{14} \frac{d^{3} \psi_{3}}{d x^{3}}=\frac{1}{b h_{c}^{3} E_{c}} q, \\
a_{12} \frac{d^{3} w}{d x^{3}}-a_{22} \frac{d^{2} \psi_{1}}{d x^{2}}-a_{23} \frac{d^{2} \psi_{2}}{d x^{2}}+\frac{1}{h_{c}^{2}} a_{24}\left[\psi_{1}(x)-\psi_{2}(x)\right]=0, \\
a_{13} \frac{d^{3} w}{d x^{3}}-a_{23} \frac{d^{2} \psi_{1}}{d x^{2}}-a_{33} \frac{d^{2} \psi_{2}}{d x^{2}}+a_{34} \frac{d^{2} \psi_{3}}{d x^{2}}+\frac{1}{h_{c}^{2}}\left[-a_{24} \psi_{1}(x)+a_{24} \psi_{2}(x)+a_{35} \psi_{2}(x)\right]=0, \\
-a_{14} \frac{d^{3} w}{d x^{3}}+a_{34} \frac{d^{2} \psi_{2}}{d x^{2}}-a_{43} \frac{d^{2} \psi_{3}}{d x^{2}}+\frac{1}{h_{c}^{2}} a_{44} \psi_{3}(x)=0,
\end{array}\right.
$$

where

$$
\begin{aligned}
& a_{11}=2 \alpha_{1} e_{2}+2 \alpha_{3} e_{1}+\frac{1}{12}, a_{12}=2 \alpha_{2} e_{2}+\frac{1}{6} x_{1}\left(3+4 x_{1}\right) e_{1}, a_{13}=\frac{1}{6}\left[1+\left(3+2 x_{1}\right) x_{1} e_{1}\right], \\
& a_{14}=1 / 4 \pi^{2}, a_{21}=a_{12}, a_{22}=2\left(x_{2} e_{2}+\frac{1}{3} x_{1} e_{1}\right), a_{23}=\frac{1}{3} x_{1} e_{1}, a_{24}=e_{1} / x_{1}\left(1+v_{b}\right), a_{31}=a_{13}, a_{32}=a_{23}, \\
& a_{33}=\frac{1}{3}\left(1+2 x_{1} e_{1}\right), a_{34}=1 / 2 \pi^{2}, a_{35}=2 /\left(1+v_{c}\right), a_{41}=a_{14}, a_{42}=a_{34}, a_{43}=1 / 8 \pi^{2}, \\
& a_{44}=1 /\left(4+4 v_{c}\right), \alpha_{3}=\frac{1}{12} x_{1}\left(4 x_{1}^{2}+6 x_{1}+3\right), \alpha_{1}=\frac{1}{12} x_{2}\left(12 x_{1}^{2}+12 x_{1} x_{2}+12 x_{1}+4 x_{2}^{2}+6 x_{2}+3\right), \\
& \alpha_{2}=\frac{1}{2} x_{2}\left(2 x_{1}+x_{2}+1\right), \alpha_{4}=\frac{1}{2} x_{1}\left(1+x_{1}\right), e_{1}=E_{b} / E_{c}, e_{2}=E_{f} / E_{c}, E_{f}-\text { Young's modulus of }
\end{aligned}
$$
facings.

\section{THREE-POINT BENDING OF THE FIVE LAYER BEAM}

\subsection{AnAlytical SOLUTiON}

The subject of the research is a simply supported sandwich beam, which carries a transverse load $F$. For this load the bending moment $M_{b}(x)=F x / 2$ for $x \in\langle 0, L / 2\rangle$. On the other hand the bending moment (from definition and the assumed hypothesis) is as follows:

$$
M_{b}(x)=-b h_{c}^{3} E_{c}\left(a_{11} \frac{d^{2} w}{d x^{2}}-a_{12} \frac{d \psi_{1}}{d x}-a_{13} \frac{d \psi_{2}}{d x}+a_{14} \frac{d \psi_{3}}{d x}\right) .
$$

So, the first equation of the system (3.4) is equivalent to the bending moment (4.1). Therefore, for further analysis purpose the system of four equations is applied: 


$$
\left\{\begin{array}{l}
a_{11} \frac{d^{2} w}{d x^{2}}-a_{12} \frac{d \psi_{1}}{d x}-a_{13} \frac{d \psi_{2}}{d x}+a_{14} \frac{d \psi_{3}}{d x}=-\frac{M_{b}(x)}{b h_{c}^{3} E_{c}}, \\
a_{12} \frac{d^{3} w}{d x^{3}}-a_{22} \frac{d^{2} \psi_{1}}{d x^{2}}-a_{23} \frac{d^{2} \psi_{2}}{d x^{2}}+\frac{1}{h_{c}^{2}} a_{24}\left[\psi_{1}(x)-\psi_{2}(x)\right]=0, \\
a_{13} \frac{d^{3} w}{d x^{3}}-a_{23} \frac{d^{2} \psi_{1}}{d x^{2}}-a_{33} \frac{d^{2} \psi_{2}}{d x^{2}}+a_{34} \frac{d^{2} \psi_{3}}{d x^{2}}+ \\
+\frac{1}{h_{c}^{2}}\left(-a_{24} \psi_{1}(x)+a_{24} \psi_{2}(x)+a_{35} \psi_{2}(x)\right)=0, \\
-a_{14} \frac{d^{3} w}{d x^{3}}+a_{34} \frac{d^{2} \psi_{2}}{d x^{2}}-a_{43} \frac{d^{2} \psi_{3}}{d x^{2}}+\frac{1}{h_{c}^{2}} a_{44} \psi_{3}(x)=0,
\end{array} .\right.
$$

The formulas of four unknown functions $w, \psi_{1}, \psi_{2}$ and $\psi_{3}$ are assumed as follows:

$$
\begin{aligned}
& w(x)=w_{1} \sin \left(\frac{\pi x}{L}\right)-w_{3} \sin \left(\frac{3 \pi x}{L}\right)+w_{5} \sin \left(\frac{5 \pi x}{L}\right)-\ldots+(-1)^{n} \mathrm{w}_{2 n+1} \sin \left(\frac{(2 n+1) \pi x}{L}\right), \\
& \psi_{1}(x)=\psi_{11} \cos \left(\frac{\pi x}{L}\right)-\psi_{13} \cos \left(\frac{3 \pi x}{L}\right)+\psi_{15} \cos \left(\frac{5 \pi x}{L}\right)-\ldots+(-1)^{n} \psi_{12 n+1} \cos \left(\frac{(2 n+1) \pi x}{L}\right) \\
& \psi_{2}(x)=\psi_{21} \cos \left(\frac{\pi x}{L}\right)-\psi_{23} \cos \left(\frac{3 \pi x}{L}\right)+\psi_{25} \cos \left(\frac{5 \pi x}{L}\right)-\ldots+(-1)^{n} \psi_{22 n+1} \cos \left(\frac{(2 n+1) \pi x}{L}\right), \\
& \psi_{3}(x)=\psi_{31} \cos \left(\frac{\pi x}{L}\right)-\psi_{33} \cos \left(\frac{3 \pi x}{L}\right)+\psi_{35} \cos \left(\frac{5 \pi x}{L}\right)-\ldots+(-1)^{n} \psi_{32 n+1} \cos \left(\frac{(2 n+1) \pi x}{L}\right)
\end{aligned}
$$

for $n \in N$, and the bending moment is developed in Fourier series

$$
M_{b}(x)=\frac{2}{\pi^{2}}\left(\sin \frac{\pi x}{L}-\frac{1}{3^{2}} \sin \frac{3 \pi x}{L}+\frac{1}{5^{2}} \sin \frac{5 \pi x}{L}-\ldots\right) F L .
$$

The functions $\psi_{1}, \psi_{2}$ and $\psi_{3}$ describe a transverse shear effect and transverse forces. Each of the above functions (4.3) and (4.4) identically satisfies boundary conditions:

$$
\begin{gathered}
\left.\psi_{1}(x)\right|_{x=\frac{L}{2}}=0,\left.\quad \psi_{2}(x)\right|_{x=\frac{L}{2}}=0,\left.\quad \psi_{3}(x)\right|_{x=\frac{L}{2}}=0, \\
\left.w(x)\right|_{x=0}=0,\left.\quad w(x)\right|_{x=L}=0, \\
\left.M_{b}(x)\right|_{x=0}=0,\left.\quad M_{b}(x)\right|_{x=L}=0 .
\end{gathered}
$$

Substituting these assumed functions (4.3) and (4.4) into the system of equilibrium (4.2) gives $n+1$ systems of equations for $k=2 i+1, i=0,1,2, \ldots, n$ : 
(4.6)

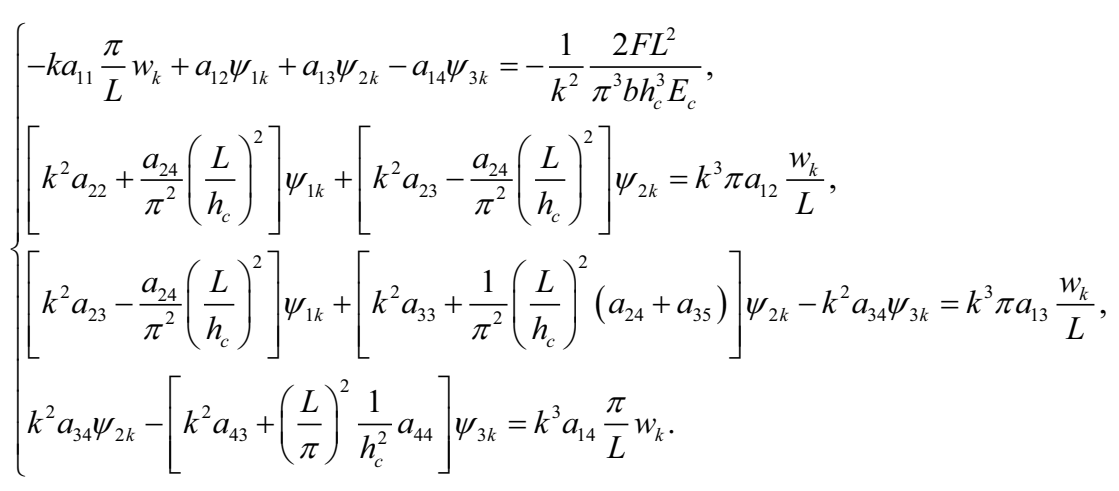

From the second, third and fourth algebraic equations of the system (4.6) unknown functions $\psi_{1 k}$, $\psi_{2 k}$ and $\psi_{3 k}$ may be calculated, namely

$$
\psi_{1 k}=\tilde{\psi}_{1 k} k \frac{w_{k}}{L} \pi, \quad \psi_{2 k}=\tilde{\psi}_{2 k} k \frac{w_{k}}{L} \pi, \quad \psi_{3 k}=\tilde{\psi}_{3 k} k \frac{w_{k}}{L} \pi
$$

where

$$
\tilde{\psi}_{1 k}=\frac{W_{\psi_{1 k}}}{W}, \quad \tilde{\psi}_{2 k}=\frac{W_{\psi_{2 k}}}{W}, \quad \tilde{\psi}_{3 k}=\frac{W_{\psi_{3 k}}}{W},
$$

and $W, W_{\psi_{1 k}}, W_{\psi_{2 k}}, W_{\psi_{3 k}}$ are the following determinants:

$$
W=\left|\begin{array}{ccc}
a_{22}+\frac{1}{\pi^{2}}\left(\frac{L}{h_{c} k}\right)^{2} a_{24} & a_{23}-\frac{1}{\pi^{2}}\left(\frac{L}{h_{c} k}\right)^{2} a_{24} & 0 \\
a_{23}-\frac{1}{\pi^{2}}\left(\frac{L}{h_{c} k}\right)^{2} a_{24} & a_{33}+\frac{1}{\pi^{2}}\left(\frac{L}{h_{c} k}\right)^{2}\left(a_{24}+a_{35}\right) & -a_{34} \\
0 & -a_{34} & a_{43}+\frac{1}{\pi^{2}}\left(\frac{L}{h_{c} k}\right)^{2} a_{44}
\end{array}\right|,
$$




$$
\begin{aligned}
& W_{\psi_{2 k}}=\left|\begin{array}{ccc}
a_{22}+\frac{1}{\pi^{2}}\left(\frac{L}{h_{c} k}\right)^{2} a_{24} & a_{12} & 0 \\
a_{23}-\frac{1}{\pi^{2}}\left(\frac{L}{h_{c} k}\right)^{2} a_{24} & a_{13} & -a_{34} \\
0 & -a_{14} & a_{43}+\frac{1}{\pi^{2}}\left(\frac{L}{h_{c} k}\right)^{2} a_{44}
\end{array}\right|, \\
& W_{\psi_{3 k}}=\left|\begin{array}{ccc}
a_{22}+\frac{1}{\pi^{2}}\left(\frac{L}{h_{c} k}\right)^{2} a_{24} & a_{23}-\frac{1}{\pi^{2}}\left(\frac{L}{h_{c} k}\right)^{2} a_{24} & a_{12} \\
a_{23}-\frac{1}{\pi^{2}}\left(\frac{L}{h_{c} k}\right)^{2} a_{24} & a_{33}+\frac{1}{\pi^{2}}\left(\frac{L}{h_{c} k}\right)^{2}\left(a_{24}+a_{35}\right) & a_{13} \\
0 & -a_{34} & -a_{14}
\end{array}\right|
\end{aligned}
$$

for $k=2 i+1, i=0,1,2, \ldots, n$.

Substituting functions (4.7) into the first equation of system (4.6) gives the amplitudes $w_{k}$ of deflection:

$$
w_{k}=-\frac{1}{k^{4}} \frac{2 F L^{3}}{\pi^{4} b h_{c}^{3} E_{c}} \frac{1}{-a_{11}+a_{12} \tilde{\psi}_{1 k}+a_{13} \tilde{\psi}_{2 k}-a_{14} \tilde{\psi}_{3 k}} .
$$

Then, the deflection $w$ in any place of the beam and the maximum deflection $w_{\max }$ (in the middle span of the beam, i.e. for $L=x / 2$ ):

$$
\begin{gathered}
w(x)=\sum_{i=0}^{n} w_{2 i+1} \sin \left(\frac{(2 i+1) \pi x}{L}\right) \sin \left(\frac{\pi}{2}(2 i+1)\right), \\
w_{\text {max }}=w\left(\frac{L}{2}\right)=\sum_{i=0}^{n} w_{2 i+1} .
\end{gathered}
$$

Based on equations (2.11), stresses of each layer of the beam are:

1. for the upper facing $\quad-\left(1 / 2+x_{1}+x_{2}\right) \leq \zeta \leq-\left(1 / 2+x_{1}\right)$

$$
\sigma_{x}^{(f 1)}\left(\frac{L}{2}, \zeta\right)=E_{f} h_{c}\left(\frac{\pi}{L}\right)^{2} \sum_{i=0}^{n} k^{2} w_{k}\left(\zeta+\tilde{\psi}_{1 k}\right), \quad \tau_{x z}^{(f 1)}=0,
$$

2. for the upper binding layer $\quad-\left(1 / 2+x_{1}\right) \leq \zeta \leq-1 / 2$

$$
\begin{gathered}
\sigma_{x}^{(b 1)}\left(\frac{L}{2}, \zeta\right)=E_{b} h_{c}\left(\frac{\pi}{L}\right)^{2} \sum_{i=0}^{n} k^{2} w_{k}\left[\zeta+\tilde{\psi}_{2 k}+\frac{1}{x_{1}}\left(\zeta+\frac{1}{2}\right)\left(\tilde{\psi}_{2 k}-\tilde{\psi}_{1 k}\right)\right] \\
\tau_{x z}^{(b 1)}=G_{b} \frac{\pi}{L} \frac{1}{x_{1}} \sum_{i=0}^{n}(-1)^{i} w_{k} k\left(\tilde{\psi}_{1 k}-\tilde{\psi}_{2 k}\right) \cos \left(\frac{k \pi x}{L}\right)
\end{gathered}
$$


3. for the core

$$
-1 / 2 \leq \zeta \leq 1 / 2
$$

$$
\begin{gathered}
\sigma_{x}^{(c)}\left(\frac{L}{2}, \zeta\right)=E_{c} h_{c}\left(\frac{\pi}{L}\right)^{2} \sum_{i=0}^{n} w_{k} k^{2}\left[\zeta\left(1-2 \tilde{\psi}_{2 k}\right)+\frac{1}{2 \pi} \tilde{\psi}_{3 k} \sin (2 \pi \zeta)\right], \\
\tau_{x z}^{(c)}=G_{c} \frac{\pi}{L} \sum_{i=0}^{n}(-1)^{i} w_{k} k\left[2 \tilde{\psi}_{2 k}-\tilde{\psi}_{3 k} \cos (2 \pi \zeta)\right] \cos \left(\frac{k \pi x}{L}\right),
\end{gathered}
$$

4. for the lower binding layer $\quad 1 / 2 \leq \zeta \leq 1 / 2+x_{1}$

$$
\begin{gathered}
\sigma_{x}^{(b 2)}\left(\frac{L}{2}, \zeta\right)=E_{b} h_{c}\left(\frac{\pi}{L}\right)^{2} \sum_{i=0}^{n} k^{2} w_{k}\left[\zeta-\tilde{\psi}_{2 k}+\frac{1}{x_{1}}\left(\zeta-\frac{1}{2}\right)\left(\tilde{\psi}_{2 k}-\tilde{\psi}_{1 k}\right)\right], \\
\tau_{x z}^{(b 2)}=G_{b} \frac{\pi}{L} \frac{1}{x_{1}} \sum_{i=0}^{n}(-1)^{i} w_{k} k\left(\tilde{\psi}_{1 k}-\tilde{\psi}_{2 k}\right) \cos \left(\frac{k \pi x}{L}\right),
\end{gathered}
$$

5. for the lower facing

$$
1 / 2+x_{1} \leq \zeta \leq 1 / 2+x_{1}+x_{2}
$$

$$
\sigma_{x}^{(f 1)}\left(\frac{L}{2}, \zeta\right)=E_{f} h_{c}\left(\frac{\pi}{L}\right)^{2} \sum_{i=0}^{n} k^{2} w_{k}\left(\zeta+\tilde{\psi}_{1 k}\right), \quad \tau_{x z}^{(f 2)}=0 .
$$

\subsection{FEM MODEL}

The finite element model of the five layer sandwich beam has been built with the use of ANSYS system. It consisted of the core modelled with the use of brick elements, two binding layers for which the same elements have been used and two facings modelled with the use of shell elements. The tie conditions have been applied between the layers. The facings were offset from the glue layers by about half of the thickness. Whole beam has been modelled. To obtain the boundary conditions corresponding to those assumed in the analytical model, all layers have been joined with a rigid plate at the both ends of the beam. Here the rigid plate distributes the applied force equally to all layers which prevents from local deformations. As to the bended beam the static analysis has been performed as a result of which the deflections and stresses have been obtained.
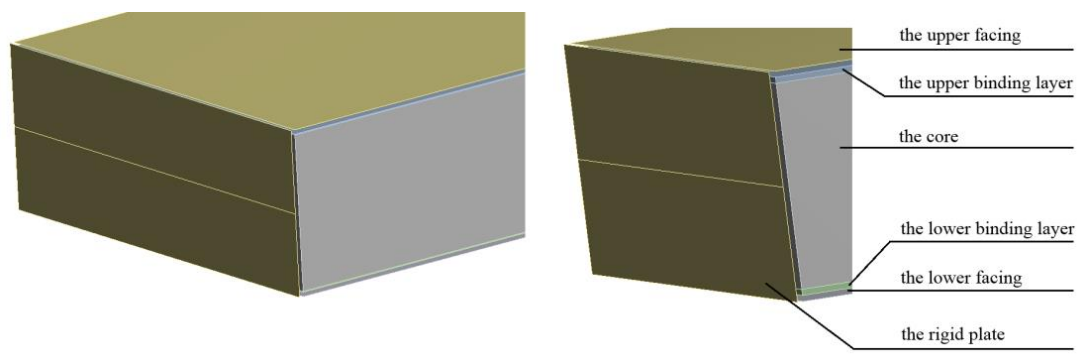

Fig 3. Numerical model of the five layer beam 


\subsection{NUMERICAL CALCULATIONS}

The example of numerical calculations for the five layer beam is presented below. The beam made of aluminium alloy is considered. The parameters of the beam are: thickness of the facings $h_{f}=1 \mathrm{~mm}$ , thickness of the core $h_{c}=17.8 \mathrm{~mm}$, thickness of the binding layers $h_{b}=0.1 \mathrm{~mm}$, Young's modulus of the facings $E_{f}=65600 \mathrm{MPa}$, Young's modulus of the core $E_{c}=700 \mathrm{MPa}$, the width $b=50 \mathrm{~mm}$ , Poisson's ratios $v_{c}=v_{b}=0.3$. The analytical results are collected with the numerical ones for different Young's moduli of binding layers. The maximum deflection and a difference (the relative error) between analytical and numerical solutions for $E_{b} \in\langle 50,1500 \mathrm{MPa}\rangle$ are shown in Table 1 and Fig 4. The analytical solutions are compared to the numerical one, and the relative error has been calculated according to the formula

$$
\varepsilon=\frac{\left|w_{\max }^{(\text {FEM })}-w_{\max }^{(\text {Analytical })}\right|}{w_{\max }^{(\text {Analytical })}} \cdot 100 \% .
$$

In analytical solution one $(n=0)$, two $(n=1)$ and three $(n=2)$ components of functions $w, \psi_{1}, \psi_{2}$ and $\psi_{3}$ are taken into account.

Tab 1. Maximum deflection $w_{\max }$ for different $E_{b}$

\begin{tabular}{|c|c|c|c|c|c|c|c|c|c|c|c|c|}
\hline$E_{b}[\mathrm{MPa}]$ & \multicolumn{2}{|c|}{50} & \multicolumn{2}{|c|}{100} & \multicolumn{2}{|c|}{250} & \multicolumn{2}{|c|}{500} & \multicolumn{2}{|c|}{1000} & \multicolumn{2}{|c|}{1500} \\
\hline \multirow{3}{*}{$w_{\max }^{(\text {Analytical })}[\mathrm{mm}] \mid \varepsilon[\%]$} & 0.0870 & 9.3 & 0.0818 & 9.5 & 0.0786 & 9.4 & 0.0776 & 9.3 & 0.0770 & 9.2 & 0.0768 & 9.1 \\
\hline & 0.0933 & 1.9 & 0.0876 & 2.3 & 0.0840 & 2.4 & 0.0829 & 2.3 & 0.0822 & 2.3 & 0.0820 & 2.2 \\
\hline & 0.0954 & 0.3 & 0.0895 & 0.1 & 0.0859 & 0.1 & 0.0846 & 0.2 & 0.0840 & 0.1 & 0.0838 & 0 \\
\hline$w_{\max }^{(F E M)}[\mathrm{mm}]$ & \multicolumn{2}{|c|}{0.0951} & \multicolumn{2}{|c|}{0.0896} & \multicolumn{2}{|c|}{0.0860} & \multicolumn{2}{|c|}{0.0848} & \multicolumn{2}{|c|}{0.0841} & \multicolumn{2}{|c|}{0.0838} \\
\hline
\end{tabular}

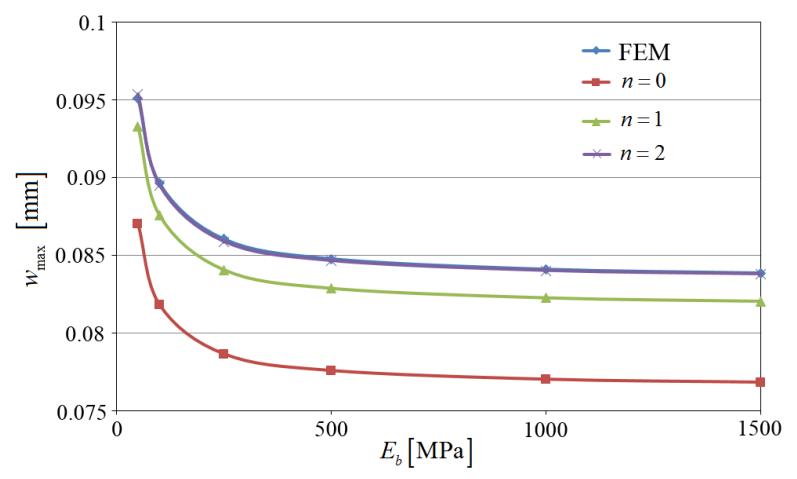

Fig 4. Maximum deflection for different $E_{b}$ 
It could be observed that with increase of Young's modulus $E_{b}$ of binding layers the deflection decreases.

Based on equations (4.11)-(4.15) stresses were obtained for $E_{b}=1500 \mathrm{MPa}$. The normal stresses have also been obtained numerically for $x=L / 2$ (in the middle span of the beam). The results are presented in Fig 5, and the selected values in Table 2.

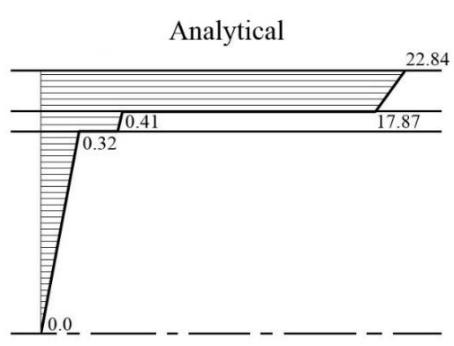

$$
\sigma_{x}[\mathrm{MPa}]
$$

FEM

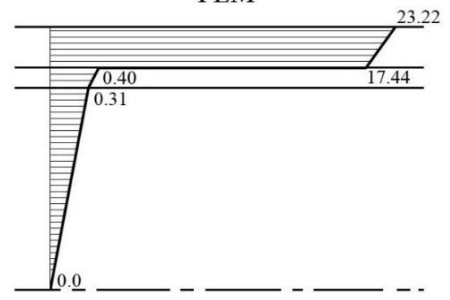

Fig 5. Normal stresses

The relative errors between analytical and numerical results have also been calculated according to the formula

$$
\varepsilon=\frac{\left|\sigma_{x}^{(F E M)}-\sigma_{x}^{(\text {Analytica })}\right|}{\min \left(\sigma_{x}^{(F E M)}, \sigma_{x}^{(\text {Analytical })}\right)} \cdot 100 \% .
$$

Tab 2. Normal stresses $\sigma_{x}[\mathrm{MPa}]$ in characteristic points

\begin{tabular}{|l|c|c|c|}
\hline \multicolumn{1}{|c|}{ Method } & Analytical & Numerical & $\begin{array}{c}\text { Relative } \\
\text { error }\end{array}$ \\
\hline$\sigma_{x}^{(f 1)}\left(\frac{L}{2},-\left(\frac{1}{2}+x_{1}+x_{2}\right)\right)$ & 22.84 & 23.22 & $1.7 \%$ \\
$\sigma_{x}^{(f 1)}\left(\frac{L}{2},-\left(\frac{1}{2}+x_{1}\right)\right)$ & 17.87 & 17.44 & $2.5 \%$ \\
$\sigma_{x}^{(b 1)}\left(\frac{L}{2},-\left(\frac{1}{2}+x_{1}\right)\right)$ & 0.41 & 0.40 & $2.5 \%$ \\
$\sigma_{x}^{(c)}\left(\frac{L}{2},-\frac{1}{2}\right)$ & 0.32 & 0.31 & $3.2 \%$ \\
\hline
\end{tabular}

The shear stresses have been calculated analytically and numerically for $x=\mathrm{L} / 4$. The results are presented in Fig 6, and the selected values in Table 3. 


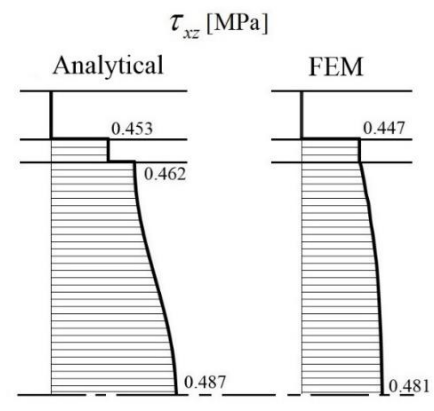

Fig 6. Shear stresses

The relative errors between analytical and numerical results are calculated similarly to the expression (4.16).

Tab 3. Shear stresses $\tau_{x z}[\mathrm{MPa}]$ in characteristic points

\begin{tabular}{|l|c|c|c|}
\hline \multicolumn{1}{|c|}{ Method } & Analytical & Numerical & Relative error \\
\hline$\tau_{x z}^{(f 1)}\left(25,-\left(\frac{1}{2}+x_{1}+x_{2}\right)\right)$ & 0 & 0 & $0 \%$ \\
$\tau_{x z}^{(b 1)}\left(25,-\left(\frac{1}{2}+x_{1}\right)\right)$ & 0.453 & 0.447 & $1.3 \%$ \\
$\tau_{x z}^{(c)}\left(25,-\frac{1}{2}\right)$ & 0.462 & 0.447 & $3.4 \%$ \\
$\tau_{x z}^{(c)}(25,0)$ & 0.487 & 0.481 & $1.2 \%$ \\
\hline
\end{tabular}

It could be observed that two components $(n=1)$ of the series $(2.25)$ are sufficient to determine the deflection. The maximal difference between analytical and numerical solutions does not exceed $2.5 \%$. In case of stresses, discrepancies are also slight. Moreover the shapes of a distribution of shear stresses are nearly the same for both analytical and numerical results (in the beam core the shear effect is occurred).

\subsection{EXPERIMENTAL INVESTIGATIONS}

In the experimental investigations a sandwich beam with a metal foam core was bended on the universal testing machine Zwick Z100/TL3S. The test stand is shown in Fig. 7. 


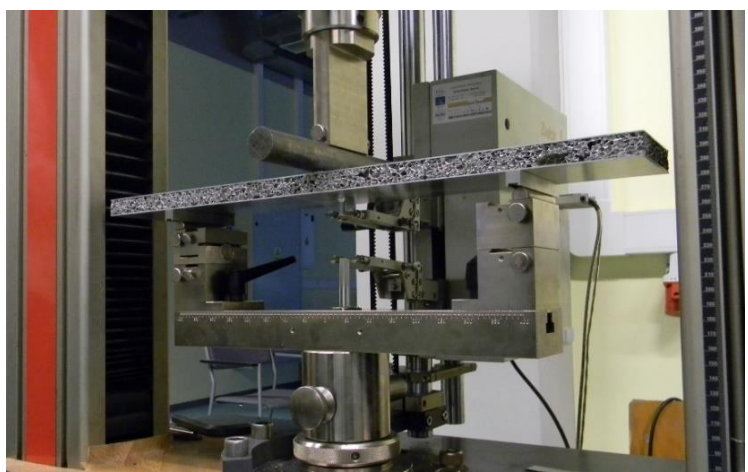

Fig 7. Test stand

The dimensions of a cross-section of the beam are as follows: the width $b=100.3 \mathrm{~mm}$, the total thickness $H=19.56 \mathrm{~mm}$, thickness of the facings $h_{f}=1 \mathrm{~mm}$. The facings were made of aluminium and the core was aluminium foam. Particular layers of the beam were glued together - thickness of the binding layers $h_{b}=0.1 \mathrm{~mm}$. The distance between supported ends of the beam was equal $400 \mathrm{~mm}$. The material constants for the aluminium alloy of the facings was $E_{f}=65600 \mathrm{MPa}$, the binding glue layers: $E_{b}=1500 \mathrm{MPa}$, and for the core $E_{c}=700 \mathrm{MPa}$ (these values of material constants are obtained from the producer of the beams).

Beam bending process was recorded - the deflection and the transverse load $F$ have been measured. The analytical and numerical calculations have also been realized for the same data. The obtained results (the maximum deflections) for $F=1 \mathrm{kN}$ are given in Table 4 .

Tab 4. The comparison of the results

\begin{tabular}{|c|c|c|c|}
\hline Method & Analytical & Numerical & Experimental \\
\hline$w_{\max }[\mathrm{mm}]$ & 1.727 & 1.726 & 1.743 \\
\hline
\end{tabular}

A good agreement can be seen between the results obtained from these methods - the difference is not greater than $1 \%$.

\section{Conclusions}

The paper is devoted to the strength analysis of a simply supported five layer sandwich beam under bending. A nonlinear hypothesis has been assumed to describe the deformation of the cross section of the beam. The influence of the mechanical properties of the binding layers has been investigated. 
It occurs that a change to the mechanical property of binding layers or its thickness is not significant for stresses and deflections. The analytical model has been built, and the problem has been analytically solved. Then numerical calculations have been conducted, and finally the experimental ones to verify obtained results. It could be observed that two components of the series are sufficient to solve analytically the strength problem. Moreover the shear effect is taken into account because of the assumed nonlinear hypothesis which is a generalization of the classical one (the broken line hypothesis).

\section{ACKNOWLEDGEMENTS}

The studies are supported by the National Science Centre in Poland - Grant No. 2013/09/N/ST8/00296.

\section{REFERENCES}

[1] M.F. Ashby, A.G. Evans, N.A. Fleck, L.J. Gibson, J.W. Hutchinson. Metal foams: A design guide. Boston: Butterworth Heinemann, 2000.

[2] J. Banhart, "Manufacture, characterisation and application of cellular metals and metal foams", Progress in Materials Science 46:559-632, 2001

[3] A. Cernescu, J. Romanoff, "Bending deflection of sandwich beams considering local effect of concentrated force", Composite Structures 134:169-75, 2015

[4] B. Gosowski, M. Kozów, "Selected problems of design of light cladding sandwich panels with lightly profiled metal faces", Archives of Civil Engineering Vol. 55, nr 3:301-21, 2009

[5] M. Grygorowicz, K. Magnucki, M. Malinowski, "Elastic buckling of a sandwich beam with variable mechanical properties of the core", Thin-Walled Structures 87:127-32, 2015

[6] P. Jasion, E. Magnucka-Blandzi, W. Szyc, K. Magnucki, "Global and local buckling of sandwich circular and beamrectangular plates with metal foam core", Thin-Walled Structures 61:154-61, 2012

[7] P. Jasion, K. Magnucki, "Face wrinkling of sandwich beams under pure bending", Journal of Theoretical and Applied Mechanics 50:933-41, 2012

[8] P. Jasion, K. Magnucki, "Global buckling of a sandwich column with metal foam core", Journal of Sandwich Structures \& Materials 15:718-32, 2013

[9] M.A.R. Loja, J.I. Barbosa, C.M. Mota Soares, "Dynamic behaviour of soft core sandwich beam structures using kriging-based layerwise models", Composite Structures 134:883-94, 2015

[10] E. Magnucka-Blandzi, K. Magnucki, "Effective design of a sandwich beam with a metal foam core", Thin-Walled Structures 45:432-8, 2007

[11] K. Magnucki, P. Jasion, W. Szyc, M.J. Smyczynski, "Strength and buckling of a sandwich beam with thin binding layers between faces and a metal foam core", Steel and Composite Structures 16:325-37, 2014

[12] K. Magnucki, M. Smyczynski, P. Jasion, "Deflection and strength of a sandwich beam with thin binding layers between faces and a core", Archives of Mechanics 65:301-11, 2013

[13] J. Małachowski, M. Klasztorny, P. Dziewulski, D. Nycz, P. Gotowicki, "Experimental investigations and modelling of Alporas aluminium foam", Modelling in Engineering 42:97-112 (in Polish), 2012

[14] S. Mohanty, R. Dash, T. Rout, "Static and dynamic stability analysis of a functionally graded Timoshenko beam", International Journal of Structural Stability and Dynamics 12, 2012

[15] A. Muc, P. Zuchara, "Optimization of sandwich structures having FRP faces", Archives of Civil Engineering Vol. 45, $\operatorname{nr} 2: 289-304,1999$

[16] M. Ostwald, "Multiobjective optimization of sandwich cylindrical shell under axial compression with core of different mechanical properties", Archives of Civil Engineering Vol. 45, nr 2:305-22, 1999

[17] F. Romanów, M. Malinowski, "Dynamic stability of sandwich cylindrical shell", Archives of Civil Engineering Vol. 45, nr 3:453-64, 1999 
[18] S.J. Salami, S. Dariushi, M. Sadighi, M. Shakeri, "An advanced high-order theory for bending analysis of moderately thick faced sandwich beams", European Journal of Mechanics a-Solids 56:1-11, 2016

[19] S. Shimizu, "Strength of sandwich plates as a girder web", Archives of Civil Engineering Vol. 45, nr 2:345-56, 1999

[20] B.H. Smith, S. Szyniszewski, J.F. Hajjar, B.W. Schafer, S.R. Arwade, "Steel foam for structures: A review of applications, manufacturing and material properties", Journal of Constructional Steel Research 71:1-10, 2012

[21] M.J. Smyczynski, E. Magnucka-Blandzi, "Static and dynamic stability of an axially compressed five-layer sandwich beam", Thin-Walled Structures 90:23-30, 2015

[22] S. Szyniszewski, B.H. Smith, J.F. Hajjar, S.R. Arwade, B.W. Schafer, "Local buckling strength of steel foam sandwich panels", Thin-Walled Structures 59:11-9, 2012

[23] S.T. Szyniszewski, B.H. Smith, J.F. Hajjar, B.W. Schafer, S.R. Arwade, "The mechanical properties and modeling of a sintered hollow sphere steel foam", Materials \& Design 54:1083-94, 2014

[24] N.Z. Wang, X. Chen, A. Li, Y.X. Li, H.W. Zhang, Y. Liu, "Three-point bending performance of a new aluminum foam composite structure", Transactions of Nonferrous Metals Society of China 26:359-68, 2016

\section{LIST OF FIGURES AND TABLES:}

Fig. 1. Scheme of the five layer beam subjected to a transverse force

Rys. 1. Schemat obciążenia pięciowarstwowej belki

Fig 2. The field of displacement - a nonlinear hypothesis

Rys. 2. Pole przemieszczeń - hipoteza nieliniowa

Fig 3. Numerical model of the five layer beam

Rys. 3. Model numeryczny pięciowarstwowej belki

Fig 4. Maximum deflection for different $\mathrm{E}_{\mathrm{b}}$

Rys. 4. Maksymalne ugięcia dla różnych wartości $\mathrm{E}_{\mathrm{b}}$

Fig 5. Normal stresses

Rys. 5. Naprężenia normalne

Fig 6. Shear stresses

Rys. 6. Naprężenia tnące

Fig 7. Test stand

Rys. 7. Stanowisko badawcze

Tab. 1. Maximum deflection $w_{\max }$ for different $E_{b}$

Tab. 1. Maksymalne ugięcia $w_{\max }$ dla różnych wartości $E_{b}$

Tab 2. Normal stresses $\sigma_{x}[\mathrm{MPa}]$ in characteristic points

Tab 2. Naprężenia normalne $\sigma_{x}[\mathrm{MPa}]$ w charakterystycznych punktach przekroju

Tab 3. Shear stresses $\tau_{x z}[\mathrm{MPa}]$ in characteristic points

Tab 3. Naprężenia styczne $\tau_{x z}[\mathrm{MPa}]$ w charakterystycznych punktach przekroju

Tab 4. The comparison of the results

Tab 4. Porównanie wyników 


\section{WYTRZYMALOŚĆ TRÓJWARSTWOWEJ BELKI Z WARSTWAMI LĄCZĄCYMI}

Slowa kluczowe: metalowe pianki, ugięcie, naprężenia, hipoteza nieliniowa, rozwiązanie analityczne

\section{STRESZCZENIE:}

Wielowarstwowe konstrukcje są badane od wielu lat i wytwarzane z różnych materiałów, w szczególności rdzeń z materiałów porowatych, komórkowych czy tworzyw sztucznych, w tym pianek metalowych. Szczególne znaczenie w budowie maszyn lub budownictwie mają te konstrukcje, które charakteryzują się dużą wytrzymałością przy stosunkowo niewielkiej masie. Takimi konstrukcjami są właśnie struktury warstwowe, których gęstość rdzenia jest znacznie mniejsza od gęstości okładzin. Z uwagi na ich charakterystyczne własności, takie jak odporność na obciążenia dynamiczne czy absorpcja akustyczna, są szeroko stosowane chociażby w budowie satelitów, statków kosmicznych, przemyśle lotniczym, samochodowym, kolejowym i stoczniowym. Konstrukcje warstwowe wytwarzane są również współcześnie, a ich modelowanie jest nadal aktualnym tematem badań, co jest zauważalne w licznych publikacjach.

Przedmiotem pracy jest analiza wytrzymałości pięciowarstwowej belki, której warstwy zewnętrzne (okładziny) połączone są z rdzeniem wykonanym z pianki aluminiowej cienkimi warstwami. Właściwości mechaniczne i fizyczne są różne dla każdej z warstw.

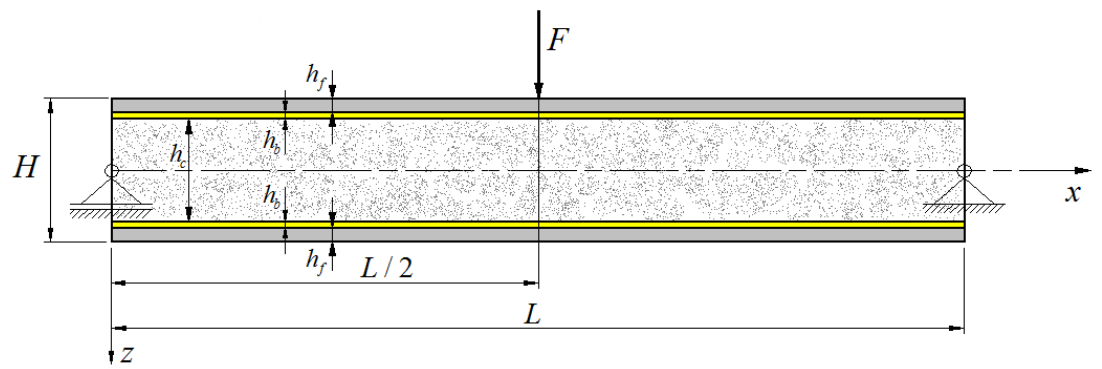

Rys 1. Schemat obciążenia pięciowarstwowej belki

Przedmiotową belkę poddano trójpunktowemu zginaniu (Rys. 1). Sformułowane zadania rozwiązano analitycznie i numerycznie. W badaniach analitycznych zastosowano nieliniową hipotezę deformacji płaskiego przekroju poprzecznego belki (Rys. 2.) 

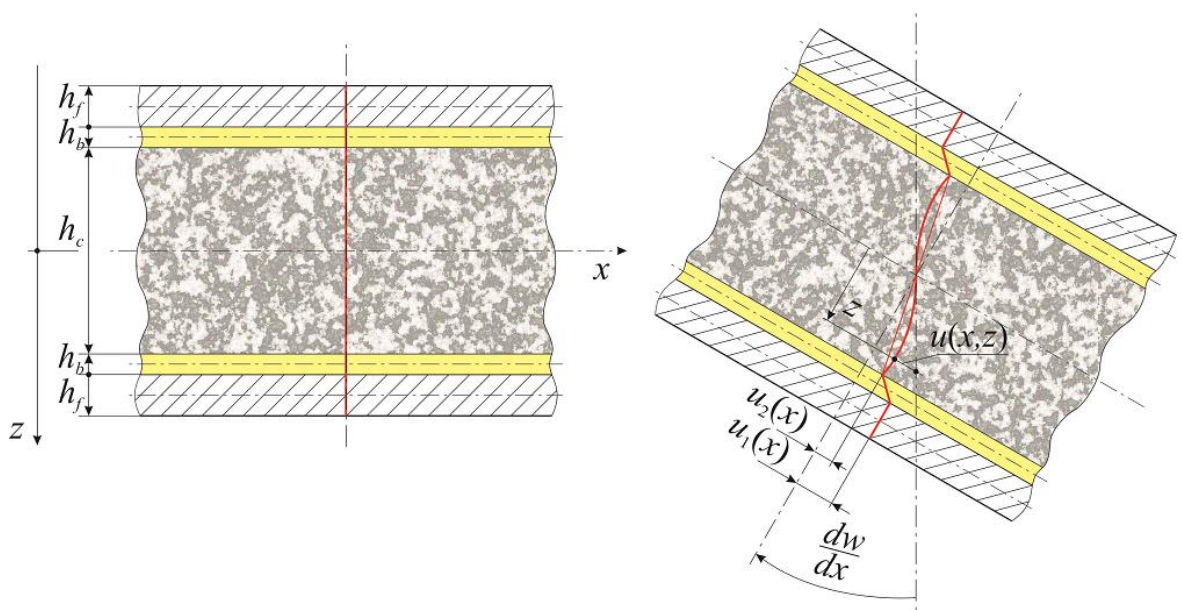

Rys 2. Pole przemieszczeń - hipoteza nieliniowa

Zdefiniowano energię odkształcenia sprężystego z uwzględnieniem przyjętej hipotezy oraz pracę obciążenia. Z zasady stacjonarności całkowitej energii potencjalnej wyznaczono układ czterech równań równowagi statycznej, który następnie rozwiązano i wyznaczono ugięcie belki oraz naprężenia. Wyniki rozwiązania analitycznego porównano z otrzymanymi numerycznie metodą elementów skończonych (ANSYS). Zwrócono szczególną uwagę na wpływ warstw łączących okładziny z rdzeniem na wartości ugięć. Wyniki otrzymane analitycznie oraz numerycznie zweryfikowano doświadczalnie. Zauważono bardzo dobrą zgodność pomiędzy wynikami otrzymanymi tymi metodami. Ponadto zauważono, że zaproponowana hipoteza nieliniowa dokładniej opisuje rozkład naprężeń tnących w konstrukcjach pięciowarstwowych. Zatem umożliwia bardziej precyzyjnie sformułować warunki wytrzymałości. Rozwiązując analitycznie problem wytrzymałości należy przyjąć przynajmniej 2 składniki rozwinięcia dla funkcji ugięcia oraz nieznanych, bezwymiarowych funkcji kształtujących pole przemieszczeń. 